\title{
First records of Taningia danae (Cephalopoda: Octopoteuthidae) in Galician waters (north-west Spain) and in Scottish waters (UK)
}

\author{
M.B. Santos*f, G.J. Pierce*, A.F. González ${ }^{\dagger}$, F. Santos ${ }^{\ddagger}$, \\ M.A. Vázquez ${ }^{\ddagger}$, M.A. Santos ${ }^{\ddagger}$ and M.A. Collins* \\ *Department of Zoology, University of Aberdeen, Tillydrone Avenue, Aberdeen, AB24 2TZ, Scotland. \\ ${ }^{\dagger}$ ECOBIOMAR, Instituto de Investigaciones Marinas (CSIC), Eduardo Cabello 6, 36208 Vigo, Spain. \\ ${ }^{\ddagger}$ Pescadería Ardora, Marqués de Quintanar no. 10, 36300 Bayona, Spain. \\ ${ }^{\int}$ Corresponding author, e-mail: m.b.santos@abdn.ac.uk
}

\begin{abstract}
Biological data are presented on two specimens of Taningia danae, an adult female caught by a trawler in Galician waters (north-west Spain) and a juvenile caught in a deep-water research trawl in Scottish waters (UK). The species has not previously been recorded in either area, although its presence has been inferred from beaks found in sperm whale stomach contents.
\end{abstract}

Taningia danae Joubin, 1931 (Octopoteuthidae) is a large deep-water squid, known to reach a mantle length of $1.6 \mathrm{~m}$ or more. The body is gelatinous, the adults lack tentacles and there are two rows of hooks on the arms. Clarke (1967) described the general morphology and anatomy, while Roper \& Vecchione (1992) reviewed the taxonomy and distribution. The photophores were described by Herring et al. (1992). The genus is monotypic.

The Octopoteuthidae are thought to be oceanic and mesopelagic, probably spawning in deep waters (Clarke, 1967). Taningia danae is cosmopolitan, mainly found in tropical and subtropical waters, but also in boreal and notalian waters (Roper \& Vecchione, 1992). Paralarvae and juveniles of T. danae were recorded by Lu \& Clarke (1975) in the mid North Atlantic $\left(53^{\circ} \mathrm{N} 20^{\circ} \mathrm{W}\right.$, i.e. west of Ireland). Evidence from sperm whale stomach contents suggests that it occurs as far as $45^{\circ} \mathrm{N}$ in the north-eastern Atlantic (Clarke \& MacLeod, 1974; Xampeny \& Filella, 1976), but no post-juvenile specimens have previously been caught in this area.

A female of this species was caught on 26 July 2000 by the pair trawler Nuevo Marina at 400-m depth in Galician waters $\left(42^{\circ} 34^{\prime} \mathrm{N} 09^{\circ} 30^{\prime} \mathrm{W}\right)$. The animal was landed in Vigo. It weighed approximately $44.5 \mathrm{~kg}$ and is thought to have been around $1 \mathrm{~m}$ in mantle length (ML). Unfortunately the complete animal could not be obtained because the mantle was sold at the fish market, apparently for human consumption. However, we were able to recover the head (lacking the beak), arms, some of the viscera (including the ovary, part of the oviduct and the stomach contents) and parts of the gladius. The largest fragment of the gladius measured $684 \mathrm{~mm}$ in length. The arms had the characteristic two rows of hooks and terminal photophore (Figure 1) and, together with the large size, this allowed positive identification of the species. The animal was a maturing or mature female, with clearly distinguishable eggs in the ovary. No eggs were present in the oviduct.

The body weight of this specimen, back-calculating from regressions given in Clarke (1986), should correspond to an animal of around 1.6 m ML. However, Clarke's regressions are based on only 15 specimens and data from Roper \& Vecchione (1992) indicate that a female of $160 \mathrm{~cm} \mathrm{ML}$ weighed $61.4 \mathrm{~kg}$. Thus, the recorded weight and approximate length estimate for the present specimen are thought to be plausible.

The stomach contents consisted mainly of fish bones, also some pieces of crustacean exoskeleton. Positive identification to species of the post-temporal bone, and the presence of gadidtype vertebrae, indicate that the fish eaten were blue whiting Micromesistius poutassou (Risso, 1826). No otoliths or cranial bones were present. Reference material from 19 blue whiting specimens was used to derive the relationship:

total length $=35.41+64.009$

The length $(3.41 \mathrm{~mm})$ of caudal vertebrae in the sample corresponded to a fish $254 \mathrm{~mm}$ in length $(5 \%$ prediction interval 238-270 mm).

The right statolith was removed and ground on both sides to clarify the growth increments. Growth increments, each consisting of an optically translucent ring and a dark ring, were counted using a semi-automatic Image Analysis System (TNPC $\left.3.0^{\mathbb{R}}\right)$, previously found to reduce counting errors in statoliths of other squid species (González et al., 1998). Statolith growth increments have been widely used for a direct estimation of ages in squids and, in several species, are laid down daily (e.g. Dawe et al., 1985). Assuming a daily periodicity in deposition of growth rings, the estimated age for the specimen studied would be 542 days. Although most small squids are thought to live around one year, some larger squid are thought to have longer life spans (e.g. Dosidicus gigans, Clarke \& Paliza, 2000).

The second specimen, a juvenile, is from a deep-water $(800 \mathrm{~m})$ trawl west of Scotland $\left(57^{\circ} 50^{\prime} \mathrm{N} 09^{\circ} 41^{\prime} \mathrm{W}\right)$ by $\mathrm{RV}$ 'Scotia'. This specimen, caught on 8 October 97, was only $32 \mathrm{~mm}$ ML. The specimen was identified from its general morphology. This is the first record for Scottish waters. The species was not recorded by Steven (1944) in his review of species occurring in Scottish waters. The only octopoteuthid mentioned from Irish waters by Massy (1928) was Octopoteuthis 


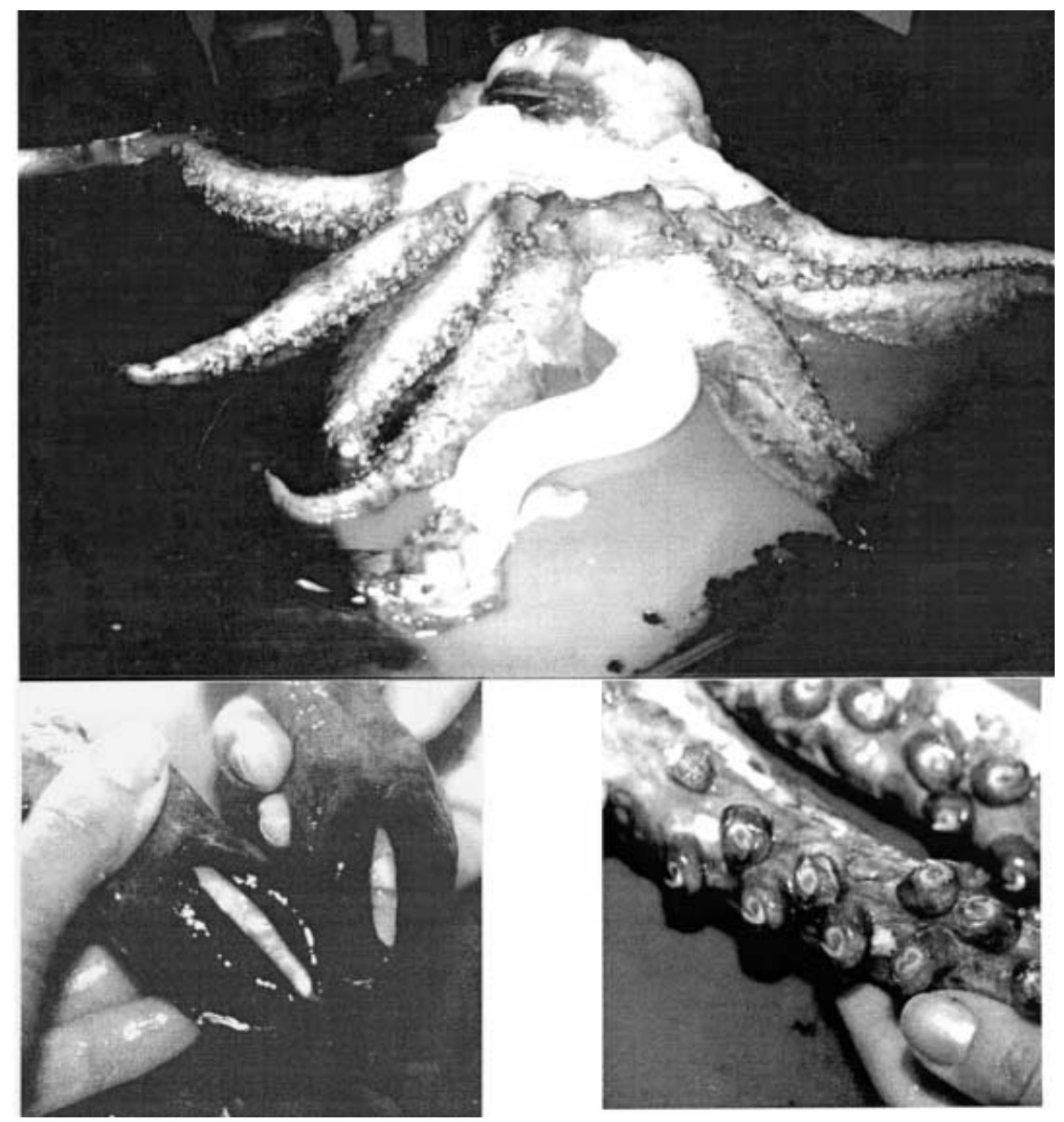

Figure 1. Photographs of the head of the specimen from Vigo and detail of hooks on the arms and the photophores.

sicula, of which four small specimens (14-107 mm ML), were caught at around $1030 \mathrm{~m}(550-570$ fathoms $)$ at $52^{\circ} \mathrm{N}-12^{\circ} 30^{\prime} \mathrm{W}$, further east than the records of $\mathrm{Lu} \&$ Clarke (1975). A larger Octopoteuthis specimen (368 mm ML) was recorded by Collins et al. (in press), in the Rockall Trough from $1504 \mathrm{~m}$ depth.

We thank the skipper of 'Nuevo Marina' for providing information on the Spanish specimen and Andrew Newton at the Fisheries Research Services Marine Laboratory in Aberdeen for providing details of the haul in which the Scottish specimen was captured.

\section{REFERENCES}

Clarke, M.R., 1967. A deep-sea squid Taningia danae Joubin, 1931. Symposium of the Zoological Society of London, 19, 127-143.

Clarke, M.R., ed., 1986. A handbook for the identification of cephalopod beaks. Oxford: Clarendon Press.

Clarke, M.R. \& MacLeod, N., 1974. Cephalopod remains from a sperm whale caught off Vigo, Spain. Fournal of the Marine Biological Association of the United Kingdom, 54, 733-750.

Clarke, R. \& Paliza, O., 2000. The Humboldt current squid Dosidicus gigas (Orbigny, 1835). Revista de Biología Marina y Oceanografía, 35, 1-39.

Collins, M.A., Yau, C., Allcock, L. \& Thurston, M.H., in press. Distribution of deep-water benthic and bentho-pelagic cephalopods from the north-east Atlantic. Fournal of the Marine Biological Association of the United Kingdom.
Dawe, E.G., O’Dor, R.K., O’Dense, P.H. \& Hurley, G.V., 1985. Validation and application of an ageing technique for shortfinned squid (Illex illecebrosus). Fournal of Northwest Atlantic Fisheries Science, 6, 107-116.

González, A.F., Macy, W.K. \& Guerra, A., 1998. Validation of a semi-automatic image analysis system to age squids and its application to age Illex coindetii statoliths. ICES fournal of Marine Science, 55, 535-544.

Herring, P.J., Dilly, P.N. \& Cope, C., 1992. Different types of photophore in the oceanic squids Octopoteuthis and Taningia (Cephalopoda: Octopoteuthidae). Fournal of Zoology, 227, 479-491.

Lu, C.C. \& Clarke, M.R., 1975. Vertical distribution of cephalopods at $40^{\circ} \mathrm{N}, 53^{\circ} \mathrm{N}$ and $60^{\circ} \mathrm{N}$ at $20^{\circ} \mathrm{W}$ in the North Atlantic. Fournal of the Marine Biological Association of the United Kingdom, 55, 143-163.

Massy, A.L., 1928. The Cephalopoda of the Irish coast. Proceedings of the Royal Irish Academy, 33, 25-37.

Roper, C.F.E. \& Vecchione, M., 1993. A geographic and taxonomic review of Taningia danae Joubin, 1931 (Cephalopoda: Octopoteuthidae), with new records and observations on bioluminescence. In Recent advances in cephalopod fisheries biology (ed. T. Okutani et al.), pp. 441-456. Tokyo: Tokai University Press.

Stephen, A.C., 1944. The Cephalopoda of Scottish and adjacent waters. Transactions of the Royal Society of Edinburgh, 61, 247-270.

Xampeny, J. \& Filella, S., 1976. Datos sobre tres cachalotes Physeter macrocephalus L. Capturados frente a las costas atlánticas de Galicia, España (Cetacea: Physeterudae). Miscelánea Zoológica, 3, 235-242.

Submitted 12 December 2000. Accepted 5 February 2001. 